4. Holmes, E.: Intranasal trentmont of Meckel's ganglion, Ans. Otol., Rhinol. and Laryngol., June, 1913.

5. Polloek, H.: Difficulties and complications of spheoopalatine ganglion injections, Ann. Otol., Rhinol, and Laryngol., 1906, xxy, 958-060.

6. Cushing, H.: Perineal zoster; with notes upon eutaneous segmentation postaxial to tho lower timb, Ax. Joun. Med. Sc., Mareh, 1904.

7. Hunt, J. R.: Herpetio infiammations of the goniculato ganglion, Tr. Am. Neurol. Assn,, 1000 ,

8. Hunt, J. R: A further contribution to the herpatio inflammations of the geviculato ganglion, Ass. Joun. Men. Sc. Aumust, 1908.

9. Hunt, J R..: Tho sensory systom of tho facial nerve and its symptomatology. Jour, Nerv. and Moot. Dis., 1008, xxxvi, 331-350.

10. Hunt, J. R.: Tho eensory field of the faeial anrvo: a further contribution to tho symptomatology of tho geniculato ganglion, Brain, 1015, xexviii, 418 .

11. Hunt, J, R.: Otalgia considered as an affection of tho soventh cranial nerve, Arch. Otol., 1907, vol, xxxvi.

12. Clark and Taylor: Tie douloureux of tho sensory filaments of the gonieulate ganglion; operation; recovery, Jour. Nerv, and Ment. Dis., 1910, xxxvii, 242, 511.

13. Clark and Taylor: Truo tio douloureux of the sensory filements of the facial nerve, Jour. Am. Med. Assn., 1909, liii, 2144.

14. Cushing, F.: Tho Bonsory distrihution of the fifth craninl nerve, Johns Hopkins Hosp. Bull., 1904, xv, 213-232.

15, Hellsten, M.: Ein Fall von Gangliọn Gasseri-Tumor, Deutsehe Ztschr. f. Nervenheilk., 1014, lii, 290-305,

10. Krausa, F.: Operatlonen in der hinteren Schïdelgrulv, Arch. f. klin. Chir., 1906, Ixxxi, 40-60.

17. Lexer, E,: Zur Operation des Ganglion Gasseri nach Erfahrungen an 15 Füllen, Areh. f. klin. Chir., 1902, 1xv, 843-928.

18. Weisenburg, $T,:$ Cerebctlopontjlo tumor diagnosed for six years as tie douloureux, Jour. Am. Ned. Assn., 1910, liv, 1000-1004.

19. Dercum, F. X., Keen, W, W., and Spiller, W. G.: Endothelioma of tho Gasserian ganglion; two succossivo resections of tho ganglion; first by tho extradural (Hartloy-Krause) operntion, and, secondly, by an intradural operation, Jour, Am. Med. Assd., 1000, xxriv, 1026-1033.

20. Frazjer, C.: An operablo tumor involving tho Gasserian ganglion, AM. Joon. Mab. Sc., 1018, clvi, 483-400.

21. Homon, E,; Zur Kenntniss dor Homiatrophia facialis und des Ursprungs des Nervus trigemlnus, Neurol, Contrabl., 1890, ix, 385, 430.

\title{
NUMBER OF RADIOGRAMS AND ROENTGEN-RAY BURNS.
}

\author{
BY W. D. WIThenBeE, M.D., \\ NAT TOAB.
}

(From the Roekefeller Inatituto for Medienl Rescareh, Now York.) .

The maximum number of exposures in a given case that can be made without producing a roentgen-ray burn, an erythema or a temporary or permanent alopecia enn be obtained by the formula used for determining unfiltered dosage. The prineiple of this formula is based upon the faet that roentgen-ray burns, alopeeia, ete., depend entirely on the quantity of a roentgen ray reaching the skin, as pointed out by Remer and Witherbee in June, 1917.1)

1 Am. Jour. Roentgenol., Juae, 1917; also a more recent artiele puhlished in Arch. Dermatol, and Syphilol., May, 1920. 
The standard formula for 1 skin unit, or the amount used for treatment of ringworm of the scalp, is expressed as follows:

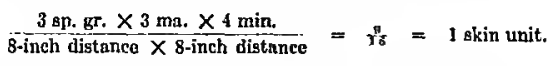

'To ilhustrate the practical applieation of the above fraction $\frac{9}{15}$, let us take the factors given in the Army Manual for the various exposures, then estimate the skin distanee from the target of the tube in each position of a patient whose measurements are a little sbove the average, substituting the skin distance in each case for the plate distanee. This formula, with the skin distanee substituted for the plate distance for an A. P. Head, would be:

$$
\frac{5 \text { sp. gr. } \times 40 \mathrm{ma},}{12 \text {-inch distauce }} \times \frac{5 \text { of a ninute }}{\times 12 \text { inch distnure }}
$$

instead of 20-inch plate distanee. This reduced to a simple frnetion equials:

$$
\begin{aligned}
& \text { I0 } 1 \\
& \frac{3 \times 10}{12} \times \frac{7 \overrightarrow{3}}{32}=\therefore
\end{aligned}
$$

If the fraction $\frac{5}{T^{8}}$ or its formula icprescnts the dose for cach exposure, then the number of plates taken to produce a temporary alopccia, or 1 skin unit, would be the mumber of times $T_{18}^{5}$ is contained

\begin{tabular}{|c|c|c|c|c|c|c|c|c|c|}
\hline & & & & Sp. gr. & $\mathrm{Mra}$ & $\begin{array}{l}\text { Times } \\
\text { minutes. }\end{array}$ & $\begin{array}{c}\text { Plate } \\
\text { distance } \\
\text { inches. }\end{array}$ & $\begin{array}{c}\text { Skin } \\
\text { diktance } \\
\text { inches. }\end{array}$ & $\begin{array}{l}\text { Number } \\
\text { of plates. }\end{array}$ \\
\hline Head, A. P. & . & . & . & .5 & 40 & $\xi$ & 20 & 12 & 2 \\
\hline Hend Lat. & . & . & . & . 5 & 40 & 10 & 20 & 14 & 5 \\
\hline Neck . & . & . & . & .5 & 40 & 3 & 20 & 16 & 14 \\
\hline Sloulder & . & . & . & . 5 & 40 & $\underbrace{}_{0}$ & 20 & 10 & 5 \\
\hline Elbow & . & - & . & . 5 & 40 & 8 & 20 & 17 & 34 \\
\hline Wrist & . & . & . & . 5 & 40 & उo & 20 & 18 & 54 \\
\hline Kiduey & . & . & . & . 5 & 40 & $7^{2}$ & 20 & 10 & 4 \\
\hline Bladder & . & 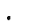 & . & . $\mathbf{5}$ & 40 & $i$ & 20 & 12 & 6 \\
\hline Hip-joint & . & 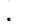 & . & . 5 & 40 & 3 & 20 & 12 & 5 \\
\hline Pelvis. & . & - & . & . 5 & 40 & 12 & 20 & 12 & 5 \\
\hline Knea . & . & . & . & . 5 & 40 & 36 & 20 & 15 & 10 \\
\hline Ankla & & & . & . 5 & 40 & th & 20 & 17 & 34 \\
\hline Lumbar spi & & & 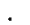 & . 5 & 40 & 3 & 20 & 10 & 4 \\
\hline Teath (slow & film) & & 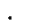 & . 5 & 40 & 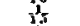 & 20 & 18 & 13 \\
\hline Teeth (fast & (ilm) & & • & . 5 & 40 & 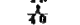 & 20 & 18 & $36=$ \\
\hline Cliest. . & . & . & . & . 5 & 40 & 19 & 28 & 16 & 11 \\
\hline
\end{tabular}
in $\frac{9}{18}$ :

$$
\frac{9}{10} \div \frac{5}{18}=\frac{0}{1 / 6} \times \frac{0}{8}=\frac{18}{5}=\frac{81}{40}=2 \frac{1}{40} \text { julates. }
$$

Therefore: 
The importance of the distanee of the skin from the target of the tube is well illustrated in the list of number of plates, espeeially in the ease of kidney and bladder exposures; here the only ehange in the four faetors is in the distanee. 'Ille differenee in clistanee is 2 inehes, whiel makes a differenee of two in the number of plates. This should make one exceedingly cautions when dealing witl exeessively large individuals whose thiekness demands the maximum exposure.

For one who is not using the army factors and who has inalvertently used the wrong faetors in a given ease to obtain the best results, and wishes to repeat the procedure, it is a simple matter to determine the dosage the skin las already received aul then deeide whether it would be safe to repeat or postpone the operation for a time.

In taking a series of plates or films, overlapping of the arens cxposed must be considered even though the factors arc correct and properly maintained throughout each cxposure

From the foregoing list of number of plates it is obvious that the head, kidney, bladder, pelvis and lumbar spine are the oncs that require the larger doses to obtain results. If a case of this kind is passed on from one roentgen-ray laboratory to another, in a comparatively slort time, and standard exposures made in each place, a roentgen-ray burn may occur. Roentgenologists, and espeeially those who specialize in the branches in which these large doses are required to obtain good plates, would apprceiate a eomplete roentgenray history as well as clinical history of these cases. By a complete roentgen-ray history is meant the time the plates were taken, the position of the patient, the factors used in making the exposures and the date of the last examination. With these data the roentgenologist eould determine at oncc low soon it would be safe to proeeed with his examination, instead of waiting three or four weeks from the date of the last exposure in order to avoid either inereasing an already produced burn or adding enough more to produee one that otherwise would be a safe and sane exposure.

Erythcma appears in from ten to fourteen days, so that at the end of thrce weeks one is safc in eoneluding, if the skin appears normal, that the exposure the patient lias lad was not suffieient to produec an crythema. But the dose may have been of such intensity that by adding the large amount necessary for the seeond examination - may induee an alopeein or erythema by the combined exposures. If an erythema or temporary alopeein has oeeurred during the third week after the first examination it would seem advisable to wait at least six weeks from the date of the last cxposure.

From a medieolegal standpoint it would seem assured that the defendant would be in a much better position to defend himself if he knew his faetors and the valuation of the same in deternining the ealse of roentgen-ray burns. 
The army factors with an interrupterless machine and a Coolidge radiator type tube whose maximum working factors are 5-inch gap and 30 ma., would mean a change from $40 \mathrm{ma}$. to $30 \mathrm{ma}$. and a proportionate inercase in the time of the exposure. For example, the factors given for an A. P. Head are 5-ineh gap, $40 \mathrm{ma}$. at 20-inch distance, with 12 seconds time. To eompensate for the one-quarter deerease in millianeter, the time given in army formula (12 seconds), would cqual threc-quarters; one-fourth would be 4 seconds and fourfourths 16 seconds, or the time neeessary to produce the same effect on the plate.

The principle involved in the adaptation of the above-mentioned .radiator tube to the army formula may be illustrated by Prof. J. S. Shcarer's rocntgenograplie formula:

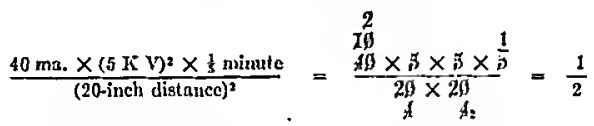

$$
\begin{aligned}
& \frac{30 \mathrm{mn} \times(5 \mathrm{~K} \mathrm{~V})^{2} \times \text { time }}{(20 \text {-inch distance })^{2}}=\frac{15}{319 \times \frac{5 \times 5 \times \mathrm{T}}{20 \times 29}}=\frac{15}{8} \\
& \frac{1}{2} \div \frac{15}{8}=\frac{1}{2} \times \frac{4}{15}=\frac{4}{15} \text { minutes }=10 \text { seconds. }
\end{aligned}
$$

By interposing $\frac{1}{2} \mathrm{~mm}$. aluminum filter, three times the number of plates may be made, and with $1 \mathrm{~mm}$. aluminum filter six times the number of plates witlout danger to the patient. Tlis is based on the time neessary to produce $1 \frac{1}{2}$ shin units of filterel roentgen ray, using $\frac{1}{2}$ and $1 \mathrm{~mm}$. alumimm filter with the army faetors and skin distance instead of plate distance. From the regular formula 12 seeonds is the time for one plate of an A. P. Hcad. Witl a skin distance of 12 inches $23^{1}$ plates ean be taken without a filter. The time necessary to produce $1 \frac{1}{2}$ filtered skin mits, which eorresponds to $\frac{3}{4}$ unit unfiltercd biologically, using $\frac{1}{2} \mathrm{~mm}$. al. = about 1 minute, 12 sceonds with $1 \mathrm{~mm}$. al. = about 2 minutes. Therefore, 1 minute and 12 seeonds $=72$ seconds $\div 12$ sceonds $=6$ plates, or thrce times the number allowed withont $\frac{1}{2} \mathrm{~mm}$. al. filter. 2 minutes $=120$ scconds $\div 12$ seconds $=10$ plates, or 5 times the number indiented without $1 \mathrm{~mm}$. al. filtcr. 